\title{
History Teaching in Vocational School Based on Curriculum 2013
}

Ajat Sudrajat $^{\mathbf{a}, \mathbf{1}}$, Dyah Kumalasari ${ }^{\mathbf{b}, \mathbf{2}}$, Danu Eko Agustinova ${ }^{\mathbf{c}, \mathbf{3}}$

a,b,c History Education Department, Faculty of Social Sciences, Yogyakarta State University

1'ajat@uny.ac.id, ${ }^{2}$ dyah_kumalasari@uny.ac.id, ${ }^{3}$ danu_eko@uny.ac.id

\begin{tabular}{ll}
\hline Article Information & ABSTRACT \\
\hline Keywords: & The Curriculum 2013 is a learning guidance for schools in \\
History, Curriculum 2013, & Indonesia. One among many schools that applied Curriculum \\
and Strategy. & 2013 is vocational school. Social sciences based majors also being \\
taught in vocational school. One of them is Indonesian History. & The major of history in vocational school is very strategic for \\
internalizing national character values. Unfortunately, history \\
teachers in vocational school don't apply suitable way in their \\
teaching. That's understandable since students in vocational \\
school focus on vocational majors. This research employs a \\
descriptive qualitative method by utilizing some techniques of data \\
collection such as observations, interviews and documentations. \\
The aim of this research is to know teaching strategy which is \\
suitable in vocational school. The benefit of this research is the \\
finding of ideal teaching strategy for vocational school students. \\
In this case, the object of research is SMK Negeri 3 Kudus. History \\
teaching in vocational school can utilize teaching media and \\
learning in historical site. Those two strategies have goal for \\
easing students of vocational school in understanding material of \\
history subject. Each of those strategies has advantages and \\
downsides, so that combination of them can cover each others \\
downsides.
\end{tabular}

\section{Introduction}

Education is a sector that determines the quality of a nation. Failure in that sector will render a nation's failure, vice versa, success in that sector automatically become a nation's success. Elements in education includes student, teacher, governent and parents. In Indonesia, base, function and purpose of national education is mentioned in Undang-Undang Sistem Pendidikan Nasional Republik Indonesia Nomor 20 tahun 2003, chapter II acts 2 dan 3 that states: Act 2 of national education is based on Pancasila and Undang-Undang Dasar Negara Republik Indonesia Tahun 1945.

The implementation of education in Indonesia under UU Sisdiknas is the development of ability and potential of student. Beside of that, through education, student hopefully can reflect nation character of Indonesia based onPancasila and Undang-Undang Dasar Negara Republik Indonesia Tahun 1945. The act of teaching history until these days merely centered in class. Teacher nearly become the main source of information in class. Students only paying attention for the 
teacher, so that student's participation is not maximum. Despite of that, the role of history major in school is so strategic in internalizing national character value of Indonesia and nationalism.

History teaching at school faces problem in its conduct. The problem must be solved in order the goal of the learning of history can be achieved. Sayono (2013: 16) states that the problem that is on the way is how to make the condition of history teaching in the present time to become an ideal history teaching. By seeing the empirical data of history teaching from current time, strategic steps toward the ideal history teaching at schools can be taken.

Brian Gurvey and Mary Krung (2015: 4) states that history teaching is not limited merely in factual knowledge. Students also must be able to understand the development of historical events imaginatively and analitically. History teachers are certain that the value of education from those majors is the ability in understanding about history which can be applied by the student both in daily living or in other field like social, culture and politic.

Curriculum 2013 is developed from standard-based curriculum and competency-based curriculum. Standard education states that national standard as the minumum quality of citizen which is detailed into content, standard of process, standard of graduate competence, standard of teacher and educational staff, standard of facilty, standard of maintenance, standard of funding and standard of educational assessment. Competency-based curriculum is designed to give learning experience as wide as possible for students in order they can develop their ability to behave, to know, to be skilled and to act (Permendikbud Nomor 70 Tahun 2013).

The Curriculum 2013 guides teachers to facilitate the development of adaptable and flexible learners who know how to take on new tasks and situations, quickly and easily. Students will need to be good communicators who can competently discuss topics with others and effectively share their ideas in many forms and for different purposes. Students must possess excellent collaboration skills and be able to work together with many different types of people, each of whom has her or his own special disciplines and unique ways of learning and working together. Furthermore, students will need the ability to create in a variety of manners and bring their visions and ideas alive through different types of media.

The development of students in the present time is in line with the development of technology in education. It provides the ability to answer the questions about the impact of technology in reconstruct the 
education system and the use of technology, in line with learning theory. While, expanded use of computer facilities and other mass media will led to the rapid transfer of information.

Among many educational institutions in Indonesia, vocational school (Sekolah Menengah Kejuruan) regarded as a leading educational institutions in the development of technology. Together with higher education institutions like university, this high school uses and develop technology extensively since its majors are vocational skills. Although most of the majors are vocational majors, social sciences are also taught there and the Indonesian History is one among those social science based majors. The major of history in vocational school is very strategic for internalizing national character values. Unfortunately, history teachers in vocational school don't apply suitable way in their teaching. That is understandable since students in vocational school focus on vocational majors.

Based on the introduction that has been explained, the author is interested to conduct a research with title "History Teaching In Vocational School Based On Curriculum 2013." The problem that wanted to be solved by this research is how to find the best strategy for teaching history in vocational school. Benefit that can be gained from this research is the finding of ideal way of teaching history for students in vocational school.

\section{Research Methods}

This research is a qualitative descriptive research which aims to know the teaching strategy which is suitable for vocational school. The object of this research is SMK Negeri 3 Kudus, a vocational shcool which is located in Central Java region. Data collection techniques that was used in this study include interviews, observations, and documentations. In this study, the main instrument of research is the researchers themselves.

Observation is the base of all sciences. Researchers can work if only there is data, i.e. the fact about reality that is acquired from observation (Nasution and Sugiyono, 2013: 226). Agustinova (2015: 37) stated that some informations that are acquired from observation include space, place, doer, activity, object, action, happening or event, time and feeling. The benefit from this technique is the researcher will become more capable to understand the context of data in overall social situation, so that a holistic view can be gained. Observation allows the researchers to gain a direct experience resulting in a chance for them to use inductive approach that isn't affected by previous concept and view. 
Document technique is a technique for collecting data by using books, documents and relevant writings for making a concept of research and discovering research object. Document research is conducted by doing many researches and citations of various relevant theories to make the research concept. This technique is also conducted for mining informations and factual data which are related or representing problems that become research object. Document is needed to support other data.

Document that is used in this research is a guide of curriculum 2013 for vocational school. The document has a function for viewing the material that are taught to students in order the goal of learning which is stated in the curriculum can be achieved. Document research allowing the researcher to compare between a document and the other. The advantages and downsides from every document can be compromised.

\section{Results and Discussions}

1. The Utilization of Multimediabased Teaching Media

In this $21^{\text {st }}$ century mediasuffused environment today, the advancement of technologies has stimulated the production of more interesting and effective approaches in teaching and learning context.
The resulting educational innovations have driven more creative developments for the interactive technologies in various forms, such as computer-based instruction (CBI), intelligent tutoring systems (ITS), integrated learning systems (ILS), computer aided assessment and computer mediated communication (FuiTheng LEOW and Mai NEO, 2014: 99). These new concepts and the developments show that the advances in the digital era have broadened the learning processes and enabled higher levels of learner interactions in order to make learning more meaningful for overcoming the insufficiency in conventional learning.

In recent years, multimedia has introduced the pedagogical strength in facilitating student learning and adding more experience in learning with the use of more than one medias. It facilitates mastering basic skills of a student by means of drill and practice. It helps in problem solving by means of learning by doing, understanding abstract concepts, provide enhanced access for teachers and students in remote locations, facilitate individualized 
and cooperative learning, helps in management and administration of classroom activities and learning content, and simulate real life problem handling environments. Multimedia Technology is used and experimented by various educational institutions of all levels all over the world in their own designed modes (S. Malik and A. Agarwal, 2012: 468). It involves the synchronisation of media in producing the media-rich outputs and is arranged in some components which are linked by the hypermedia. Students can navigate to the source of information in a shorter time, build the connections between relevant topics, and construct their knowledge by associating to the meaningful information (Fui-Theng LEOW and Mai NEO, 2014: 100).

Like any other major, history which emphasizes on the meaningfulness of the lesson also needs a suitable media. Moreover if the case is history teaching in vocational school. That is because students in vocational school accustomed to do practical learning rather than theoritical in which a simpler media for teaching and learning is needed. The learning trait of vocational students is also emphasized by Dale (1969) who stated that learners can retain $5 \%$ of what is heard, $10 \%$ of what is read, $20 \%$ of what is obtained in audiovisual presentations and the retention rates can be increased to $70 \%$ and above when encouraging the learners to do hands-on practical work in learning process. This shows that learning environment is important in retaining the retention in the learning process.

Multimedia technology adds new dimension to learning experiences because the concepts are easier to be presented and comprehended when the words are complemented with images and animations. Stating further that it has been established that learners retain more when more of senses are engaged in the learning process the intensity of the experience aids retention and recall by engaging social, emotional and intellectual senses (Ogunbote \& Adeyose in Okedeyi et al., 2015: 150). Therefore, a teaching and learning media for history major which requires the student to become active in a practical work will be a suitable choice. 
Beside the practical learning trait of its students, vocational school also lacks of learning hour. Unlike the ordinary senior high school that given six hours for history major per week (two hours for general history and four hours for Indonesian history), vocational school only given two hours per week. Seeing the reality, a learning of history that allows the student to be active is needed in order to deal with the relatively limited learning hours. Because of that, teaching and learning method that viewed as the most effective is by using information and technology (IT) based media.

Yuli Kwartolo (2010: 15-43) explained about some models of teaching media with technology base including: internet, e-learning, e-mail, power point, learning CD and languange laboratory. The learning and teaching must be supported by IT devices but the problem is the availability of those devices. To overcome the availability issue, Kwartolo concluded that the teaching of history must be done effectively and make students pay attention because the teaching is interesting, innovative and creative.

a. Video

The era also drives the way of history teaching to become more interesting and innovative. Relating to the view of Prof. Susanto Zuhdi as the Senior Professor of History from Universitas Indonesia, the creation of history learning contents in video form can be conducted if the teaching is an IT-based teaching. Thus, video based learning media is chosen in this research. Video can help the students to imagine and to understand historical event or the material that is being taught. As the result, teachers during the early semester must prepare the teaching media that will be used for the whole semester. When the semester is going by, they won't be bothered to make the video or any teaching media of history.

The term media is very popular in communication field. In essence, teaching and learning is a process of communication, i.e. the process of tranferring a message from the source through a channel or certain media to the receiver. The communication process itself is just happened after a feedback. The 
communication channel which is used to carry or sending a message is the way or mean in which the message can pass between the communicator and communicatee. In order to make the communication process become effective and efficient, the teacher must use a media to stimulate student in studying (Prasetya, 2015: 1).

The media which is used in learning allows the student to get wider and more complete learning experience. The wideness of material that has been gotten by the student will sprout a new interest in learning. The concept that is explained by the media can be served in a recreational and interesting way. Teaching media has an important role as a component in learning system. Without media, the communication won't work well. Teaching media is an integrative part from teaching system. One of the ways to overcome the burden of the communication process is the teaching media. Because of that, knowledge about teaching media is very important to be known and understood by all people who are involved directly or inderectly with the teaching.
Teaching media of history in video form can be made with some variations. Those variations won't make the students feel bored every time they watch the videos that have been made by the teacher. Videos that are made by teacher is a way to bulid the critical sense and understanding of the student toward the event in history. Thus the utilization of video as a teaching and learning media can increase student's understanding. In outline, the contents of the video include:

1) Main material

2) Standard of competence

3) Goal of the learning

4) Historical event

5) The place of the event

6) Historical remain

Video that is mentioned in this research is not only a video of human's activity in historical event, but also a video in the form of animation. For example, the chapter about the arrival of Westerners in Nusantara. The contents of the animation include the background of the arrival of Westerners in Nusantara, the way they came and places that were visited by them. The media itself hopefully can become a more interactive way for 
learning history (Ilham Eka Putra, 2013: 25). Besides the animation, it is also possible to use videos from archieves of certain institution that are related to the teaching material. b. Augmented Reality (AR)

Many people think that Augmented Reality (AR) is the evolution of virtual reality. Today it is clear that they are two technologies with different research and development paths and usages. Augmented reality technology integrates digital information with real environments in which people live. Everything is processed and produced in real time. This is one of the main differences with virtual reality, which uses artificial environments. Augmented reality uses the real world and completes it with digital information. Basically, it increases the amount of information that a human can take from the environment (Curcio, et al. in M. Fernandez, 2017: 2-3).

The development of AR was started around 1957-1962 when Morton Heilig, an American cinematographer, created and got a patent of his simulator that was called Sensorama which combined visual, vibration and aroma effects. On 1966, Ivan Sutherland invented the head-mounted display that was claimed as the window of virtual world. On 1975, a scientist named Myron Krueger invented Videoplace which, for the first time, allowed the user to interact with virtual object. On 1989, Jaron Lanier introduced the Virtual Reality and built the first commercial bussiness in online world. On 1992, he developed the AR to repair Boeing's airplane. On the same year, LB Rosenberg developed one of the AR's functions that is called Virtual Fixtures (Afdal et al., 2011: 3).

Augmented reality is one of the variations of virtual reality and can be seen as introduction of artificial stimuli over real ones, with the use of multisensory technology. In other words, it includes virtual information on human senses, enhancing men-environment relationship. The main characteristics present in AR are: mix of virtual elements in the realcontext; interactivity with resultant reality; positioning of virtual objects in a coherent manner according to the reality in question 
and influence over all senses

(Azuma et al. in Rezende et al. 2017: $100)$.

AR combines various electronic medias/devices such as camera, computer devices and marker (a virtual line as a border). AR displays the combination of virual result in a media (video or reality). Before making an AR product, the program must make some adjustments based on the data to detect the AR model that will be displayed. If the received data is match, the marker will renders three dimention (3D) pictures that can be seen from many sides.

AR creates an intentional illusion that we can use to enrich the sense of vision. This allows us to include information of the surroundings in our sight or of any other relevant data at the time, like schedules, notifications, updates, etc. Naturally this feature can be used in education and there are many projects involving it. The fact that we can mix reality with virtual objects is, at least, an interesting prospect (Rezende et al. 2017: 100).

AR serves pupose as a device that is used in various fields like education, engineering, entertainment and military. In education, AR becomes a device to help teaching so that the student can understand the lesson easily. AR can help the learning of various sciences especially anatomy of biology. For example, Carlos III University in Spain developed AR on 2013 that is called Augmented Lecture Feedback System (ALFS). It can detect the student's difficulties when learning at the campus. Unfortunately, the lecturer must use a special eyeglasses to communicate with the student while using the system (Panji, 2014).

Haller, Billinghurst, and Thomas (2007) in Ahmad Burhanudin (2017: 2) explained that $\mathrm{AR}$ is a combination of real-time system and digital content in which in the building process, it combines computer program and the situation in real world. It can be applied in an Android based smartphone. The smartphone regarded as a vast platform for a good development of AR. Mobile technologies allow providing information about real life objects such as places and buildings not only in a virtual space, but also in real contexts, based on the user's current position or even 
bearing. Mobile technologies can potentially promote, facilitate, and enhance student collaboration and interaction - processes that serve as a means for accessing, discovering, discussing, and sharing information. Therefore, mobile technologies extend learning beyond classrooms and homes to any possible site such as airports, train stations, markets and the outside world in general (Martin Wolpers et al., 2011: 72-73). Ahmad Burhanudin explained that AR has two forms, Marker Augmented Reality (Marker Based Training) and Markerless Augmented Reality.

1) Marker Augmented Reality

This method utilizes black and white lines to create AR. The Marker can be identified by a computer for operating AR. This method has been used since 1990s and has been applied in AR production.

2) Markerless Augemented Reality

This method doesn't need black and white lines (marker) to create AR. Digital elements can be displayed directly. This method utilizes some techniques like face tracking (algorithm for identifying objects around the face), 3D Object Tracking (identifies all objects), and Motion Tracking (identifies all idle and moving objects).

Ramdan Febriawan (2010) explained that $\mathrm{AR}$ is an interesting method if it is applied in learning at school. AR is still being used by engineering-education institution, but it won't be impossible if institutions from other field use this "4.0 technology." AR is very important in education since it can bring some advantages like effectivity and effciency in learning, motivation building, interaction and teamwork. Even, AR is regarded as suitable for pre-scool education and vocational school like SMK. Kementerian Pendidikan dan Kebudayaan (Ministry of Education and Culture) has commitment to apply AR technology in vocational schools. AR viewed by the Ministry as a better solution than VR. Because of that, SEAMEO Regional Open Learning Center is involved to develop it. It is understandable since s an extension 
to VR systems, AR systems can be extremely effective in providing information to a user that deals with multiple tasks at the same time (Kalawsky et al., 2000: 39-46). Previous studies (Boud A. C., et al., 1999: 32-36) have shown that they can improve performance times when the training is conducted on real objects. It can become the best solution for the time being as a connector between the online world and reality (Neneng Zubaedah, 2018).

$\mathrm{AR}$ is suitable to be applied in a learning process in vocational school since the school applies learning by practice. Although it is regarded as suitable, it has some advantages and downsides like any other learning method. That will become a challenge for the teacher to innovate and improve the learning in vocational school.

The implementation of AR in vocational school has some advantages. Due to practicallearning characteristic of vocational school, AR can help the teacher to explain industrial-based teaching material. For example, a teacher who teaches automotive major can explain about the internal system of a vehicle much easier with the help of AR. The student will also be able to understand the material easily such as the operation of combustion system. Also, the AR will become a great help if it is used to explain material about history. The display and illustration of AR will interest the students and won't bore them in learning industrial-based material. The access to AR application in students' Android phones will also become a great help for the implementation of $A R$ in vocational school.

Despite of the advantages from its implementation, it still has some downsides. Most of the teachers do not have ability to create AR-based teaching material. They still depend on outside developer in creating the material. For the students, the AR technology hasn't available especially for those who are in the outer-most and under-developed regions. Even Android technology is still rare. Without Android system, the AR-based learning cannot be implemented. So, the AR-based learning will be limited in urban regions due to Android system availability problem. 
The effort to overcome the downside of AR implementation for the teacher can be done by holding intensive training about creating AR-based teaching material for the teacher. With the training, hopefully, the teacher of industrial-based majors can utilize AR in their teaching process since the majors are the main skill for students of vocational school. And for the outer-most and under-developed regions, the government must give aid to develop IT in those regions.

\section{Historical Site Visit}

Museums are places where historical and cultural elements are kept alive (Tulay Ocal, 2016: 378). Even people's beliefs, life styles and psychological conditions can be understood and cultural transmission is provided. For several centuries it is become clear that museums and their spaces have become very significant tourist attractions. Thanks to the relationship between these spaces and their urban environment, the citizens are now aware of a series of cultural values that they consider as their own (Panosa, 2012: 146). Beside of that, on-site learning as a peer interaction outside the classroom should also enhance learning since peer interaction outside class time plays a key role in academic success (Bloom in Jacobs, 2013: 2). Students get the opportunity to work actively with tangible evidence by encountering alternative learning ways (Şahan in Ocal, 2016: 378). For some students this means finding the opportunity to discover their own abilities and skills that cannot be discovered in a traditional classroom setting. Class activity at museums increases students' academic knowledge about history and cultural heritage and their sensitivity towards it.

Doing a visit to historical sites sorrounding the school or on-site learning would be a suitable strategy for increasing the student's understanding in learning history. The moment for doing such kind of out-of-class activity can be conducted when there is matching occasion. For an instance, when explaining about the chapter of Dutch colonialism in Indonesia, the teacher together with the students, visit a relating site sorrounding the school. On the site, the teacher explains about the historical event 
that took place in the area, the background story of Dutch arrival to the area and the remain like Dutch building styles or ornaments that adorn the site.

Strategy for on-site taching can be designed by teacher with some decision. The first way is by deviding the students into some groups. Each group will be given a task to identify the Dutch Colonial building and find every information about the building. Every group that has completed their finding will report their finding while the other groups is hearing their report. After that, a discussion to give questions and critiques will be held and finally the teacher gives a respond to the report. This first way has a major downside where the students can give incorrect information about their finding. That is why the teacher must also give correction if there is an error in the understanding and the way the students give question.

The second way is by explaining every detail of a Dutch building and background event that happened on the site. The students can pay attention to the teacher about the topic that is being explained. If the students confused, the teacher can let them to ask question. Unlike the first way that allow the student to explore and make their own discovery, this second way is rather theoritical and teacher centered learning. This way is certainly against the point in Curriculum 2013 that demands a student centered learning. Because of that, a combination of those two ways would be more preferable since the learning needs flexibility that depends on the situation in the field.

\section{Conclusion}

The teaching of history in vocational school must have a special strategy which is needed to achieve the goal of the learning of history. Students in vocational school have special characteristic compared to other kind school which will affect in teaching media application and teaching strategy that is used by teacher. In this case, SMK Negeri 3 Kudus also has the same issue. Strategy that can be used for the teaching in vocational school can be a teaching with help video-based and AR-based teaching media or out of class learning in a historical site. Those two strategies will help the student to understand the historical event and learning material that has been taught 
by teacher. Combining the strategies promising a solution, since each advantage of the strategy can cover others downside. Finally, the application of the strategy is on the teachers' hand in which it will depend on the characteristic of the student in vocational school.

\section{References}

Afdal, M dkk. 2018. "Penerapan Teknologi Augmented Reality pada Media Pembelajaran Lapisan Permukaan Bumi Berbasis 3D”. Jurnal Ilmiah Rekayasa dan Manajemen Sistem Informasi, Vol. 4, No. 1, Februari 2018, pp. 1-10.

Ahmad Burhanudin. 2017. Pengembangan Media Pembelajaran Augmented Reality Pada Mata Pelajaran Dasar Elektronika di SMK Hamong Putera 2 Pakem. Skripsi. Yogyakarta: Universitas Negeri Yogyakarta.

Agustinova, Danu Eko. 2015. Memahami Metode Penelitian Kualitatif: Teori dan Praktik. Yogyakarta: Calpulis.

Boud A. C., Haniff D. J., Baber C., Steiner S. J. 1999. "Virtual Reality And Augmented Reality As A Training Tool For Assembly Tasks." In Proceedings of the International Conference on Information and Visualization. Pp. 32-36.

Dale, E. (1969). Audiovisual Methods In Teaching (3rd ed.). New York: The Dryden Press; Holt, Rinehart \&Winston.

Fernandez, M. (2017). “Augmented virtual reality: How To Improve Education Systems." Higher Learning Research
Communications. Volume 7, Issue 1, pp. 1-15.

Fui-Theng LEOW and Mai NEO. 2014. "Interactive Multimedia Learning: Innovating Classroom Education In A Malaysian University." The Turkish Online Journal of Educational Technology. April 2014, Volume 13, Issue 2, pp. 99110.

Jacobs, George M. (2013). And, Out of Class Too: The Who, What, When, Where, Why, and How of Students Learning Together Outside of Class. Singapore: James Cook University.

Kalawsky R. S., Hill K., Stedmon A. W., Cook C. A., Young A. "Experimental Research Into Human Cognitive, Processing In An Augmented Reality Environment For Embedded Training Systems." Virtual Reality. Volume 5, Issue 1, (2000), pp. 39-46.

Krung, Marry, et.al. (2015). Model-Model Pembelajaran Sejarah di Sekolah. Yogyakarta: Ombak.

Kwartolo, Yuli. (2010). Teknologi Informasi dan Komunikasi dalam Proses Pembelajaran. Jurnal Pendidikan Penabur No. 14 Tahun ke-9 Juni 2010. Jakarta: BPK Penabur pp. 15-43.

Neneng Zubaedah. (2018). "SMK Akan Dibekali Augmented Reality". Koran Sindo. Accessed from https://nasional.sindonews.com/rea d. Accessed on September $24^{\text {th }}$, 2018 at 21:20.

Ocal, Tulay. (2016). "The Effect of Field Trips to Historical Cultural Heritage Sites on Teacher Candidates' Academic Knowledge and Their 
Sensitivity." Creative Education. No. 7, pp. 376-386.

Okedeyi, Abiodun S., Oginni, Aderonke M., Adegorite, Solomon O., \& Saibu, Sakibu O. (2015). "The Relevance Of Multi Media Skills In Teaching And Learning of Scientific Concepts In Secondary Schools In Lagos State, Nigeria." Journal of Education and Practice. Vol.6, No.15, (2015), pp. 150-154.

Panji. (2014). "Pemanfaatan Augmented Reality (AR) Dalam Dunia Pendidikan." Accessed from https://www.nurulfikri.ac.id/index.p $\mathrm{hp} / \mathrm{id} /$ artikel/item/324. Accessed on September $24^{\text {th }}, 2018$ at 19:31.

Ramdan Febrian. (2018). "Sekolah Bisa Lebih Seru dengan Teknologi Augmented Reality". Tirto. Diakses melalui https://tirto.id. Accessed on September $24^{\text {th }}, 2018$ at 21:30.

Rezende, W., Albuquerque, E. and Ambrosio, A. "Use of Augmented Reality to Support Education Creating a Mobile E-learning Tool and using it with an Inquiry-based Approach." Proceedings of the 9th International Conference on Computer Supported Education. Volume 1, (2017), pp. 100-107.

S. Malik and A. Agarwal. (2012). "Use of Multimedia as a New Educational Technology Tool - A Study." International Journal of Information
Panosa, Maria Isabel. "Historical and Archaeological Heritage and its Social Transfer: Contributions and Challenges." International Journal of Humanities and Social Science. Vol. 2, No. 22, November 2012, pp. 146-151.

Peraturan Menteri Pendidikan dan Kebudayaan Nomor 70 Tahun 2013.

Putra, Eka Ilham. (2013). "Teknologi Pembelajaran Sejarah Melalui Pemanfaatan Multimedia Animasi Interaktif." Jurnal TEKNOIF. Vol. 1, Edisi 2 Oktober 2013. Padang: Insitut Teknologi Padang.

and Education Technology. Vol. 2, No. 5, October 2012, pp. 468-471.

Sayono, Joko. (2013). "Pembelajaran Sejarah di Sekolah: Dari Pragmatis ke Idealis." Jurnal Sejarah dan Budaya. Volume 7, Nomor 1, Tahun 2013.

Sugiyono. (2013). Metode Penelitian Kuantitaif, Kualitatif, dan R\&D. Bandung: Alfabeta.

Wolpers, Martin, et al. (2011). "Enabling Mobile Learning Experiences for Architecture Education." Augmented Reality in Education: Proceedings of the "Science Center To Go" Workshops. Athens: Ellinogermaniki Agogi. 